\title{
Do Common Variants Separate between Obese Melanocortin-4 Receptor Gene Mutation Carriers and Non-Carriers? The Impact of Cryptic Relatedness
}

\author{
Jessica Mühlhaus ${ }^{a}$ Carolin Pütter ${ }^{b}$ Harald Brumm ${ }^{a}$ Harald Grallert ${ }^{c}$ \\ Thomas Illig ${ }^{c}$ Susann Scherag ${ }^{d}$ Thomas Reinehre Wilfried Pott ${ }^{f}$ \\ Özgür Albayrak ${ }^{d}$ Hai-Jun Wang ${ }^{g}$ Anne-Madeleine Bau ${ }^{a}$ Susanna Wiegand ${ }^{a}$ \\ Annette Grüters $^{a}$ Heiko Krude ${ }^{a}$ Johannes Hebebrand ${ }^{d}$ Anke Hinney ${ }^{d}$ \\ Heike Biebermann ${ }^{a}$ André Scherag ${ }^{b}$

\begin{abstract}
a Institute of Experimental Pediatric Endocrinology, Charité Campus Virchow-Klinikum, Berlin, ${ }^{\mathrm{b}}$ Institute for Medical Informatics, Biometry and Epidemiology, University of Duisburg-Essen, Essen, 'Helmholtz Zentrum München, German Research Center for Environmental Health, Institute of Epidemiology, Munich, ${ }^{d}$ Department of Child and Adolescent Psychiatry and Psychotherapy, University of Duisburg-Essen, Essen, eVestische Hospital for Children and Adolescents, University of Witten/Herdecke, Datteln, and fDepartment of Psychosomatics and Psychiatry, Red Cross Children's Hospital Siegen, Siegen, Germany; ${ }^{9}$ Division of Maternal and Child Health, School of Public Health, Peking University, Beijing, China
\end{abstract}

\section{Key Words}

Obesity $\cdot M C 4 R \cdot$ Mutations $\cdot$ Haplotypes $\cdot$ Cryptic relatedness

\begin{abstract}
Background/Aims: Genome-wide association studies revealed associations of single nucleotide polymorphisms (SNPs) flanking MC4R with body mass index variability and obesity. We genotyped 28 SNPs, covering MC4R, and searched for haplotypes discriminating between obese mutation carriers and non-carriers. Methods: We analyzed all three-marker haplotype combinations of the 28 SNPs to discriminate between obese mutation carriers and non-carriers - overall and in functional categories for 25 different MC4R mutations: (a) 'like wild type', (b) 'partial loss of func-
\end{abstract}

tion', and (c) 'complete loss of function'. We checked for the possible impact of 'cryptic relatedness' by sensitivity analyses including only 1 randomly selected patient per mutation. Results: Overall analyses revealed a haplotype of 3 SNPS downstream of the MC4R discriminating between obese mutation carriers and obese non-carriers. However, sensitivity analyses showed that the finding is most likely due to cryptic relatedness. Conclusion: Given a mutation prevalence of $1-5 \%$, the sample size of 62 obese mutation carriers with overall 25 different $M C 4 R$ mutations represents a unique feature of our study. Taking MC4R as an example, we demonstrate the impact of cryptic relatedness when trying to link non-coding SNPs to functionally relevant mutations. Hence, a thorough mutation screen can currently not be guided by SNP genotyping.

Copyright $\odot 2012$ S. Karger AG, Basel

\section{KARGER}

Fax +4161306 1234

E-Mail karger@karger.ch

www.karger.com
(C) 2012 S. Karger AG, Basel

$1663-2818 / 12 / 0776-0358 \$ 38.00 / 0$

Accessible online at:

www.karger.com/hrp
Dr. André Scherag

Institute for Medical Informatics, Biometry and Epidemiology

University of Duisburg-Essen

Hufelandstrasse 55, DE-45122 Essen (Germany)

Tel. +49 201723 4793, E-Mail Andre.Scherag@uk-essen.de 


\section{Introduction}

Genome-wide association studies (GWAS) have contributed to a growing number of robustly confirmed genetic association signals for common single nucleotide polymorphisms (SNPs) and complex traits such as obesity $[1,2]$. The latest meta-analysis of the GIANT (Genetic Investigation of ANthropometric Traits) consortium evaluated approximately 250,000 individuals for genetic variants that are associated with body mass index (BMI) [3]. The analyses revealed 14 known and 18 new genetic loci. These loci imply the existence of regulatory or coding variants in nearby genes. Prominent examples of these GWAS-based candidate genes for obesity are FTO (fat mass and obesity-associated gene) [4-6], TMEM18 (transmembrane protein 18 gene) [7, 8], and MC4R (melanocortin-4 receptor gene) [8-12]. With regard to functional characterization and biological pathways, the $M C 4 R$ represents one of the most promising candidate genes. The MC4R codes for a G-protein-coupled receptor which is involved in the hypothalamic regulation of appetite and energy balance [13]. Moreover, to date, more than 150 different $M C 4 R$ mutations have been identified and more than half of these mutations modify receptor expression and/or function in in vitro assays [14]. GWAS analyses also revealed association of several common variants outside the $M C 4 R$ coding region with $\mathrm{BMI}$ variability and obesity. Interestingly, initial analyses detected the SNPs rs17782313 [9] and rs12970134 [10] 150 and $188 \mathrm{~kb}$ downstream of the MC4R coding region, whereas more recent analyses also implied common variants in the upstream region $[3,15]$.

Here we investigated the genomic region flanking the $M C 4 R$ for an association between common non-coding SNP alleles (and haplotypes thereof) and 25 different, naturally occurring and functionally characterized MC4R mutations. We performed comparisons of SNP allele and haplotype frequencies of obese individuals who are carriers or non-carriers of MC4R mutations. We analyzed the mutations in subgroups according to functional categories and explored the impact of so-called 'cryptic relatedness' (i.e. kinship among cases or controls that is not known to the investigator) on our results. The classification of the mutations into functional categories and the subsequent analyses according to these categories was driven by both statistical and biological considerations: (i) from a statistical point of view, we aimed to avoid problems of misclassification by comparing obese carriers of $M C 4 R$ mutations that were functionally characterized as 'like wild type' in the used in vitro system to obese carri- ers without $M C 4 R$ mutations which could contribute to a diluted overall effect if present; (ii) from a biological point of view to discriminate between mutations having a relevant effect on receptor function in comparison to wild type (WT) and MC4R mutations without a relevant functional effect in comparison to WT. For some diseasecausing genes a haplotype was reported to be associated with several mutations [16-18]. In this context, cystic fibrosis can serve as an example, as it has been shown that certain risk microsatellite alleles are indicative of diseasecausing mutations in the cystic fibrosis transmembrane conductance regulator gene (CFTR) suggesting a single origin for most CFTR mutations [16, 17].

Correspondingly, we explored the possibility that a common risk haplotype may indicate a functionally relevant $M C 4 R$ mutation.

\section{Methods}

\section{Study Groups}

The analyzed mutation carriers derived from a large study group of (extremely) obese German young and adult individuals (Hebebrand group in Essen and formerly Marburg, Germany); individuals were screened for $M C 4 R$ mutations within the coding region. A number of different non-synonymous, frameshift and nonsense mutations, silent variants and two polymorphisms in the MC4R (p.Val103Ile; p.Ile251Leu) were identified; most of them were detected just once, but some in several individuals (up to 17) $[12,19-22]$. Here we describe 25 different $M C 4 R$ mutations in a total of 62 (extremely) obese mutation carriers and 28 screened obese non-carriers. Descriptive statistics of all 90 obese individuals are displayed in table 1 . The study was reviewed and approved by all local IRB boards and conducted in accordance to the guidelines of the Declaration of Helsinki. Written informed consent was obtained from all subjects and, in case of minors, their parents.

\section{SNP Selection and Genotyping}

In total, 28 SNPs were chosen for genotyping in the 90 obese individuals (fig. 1). 23 of the 28 SNPs are located between $60 \mathrm{~kb}$ upstream and $40 \mathrm{~kb}$ downstream of the MC4R coding region on chromosome 18q21, reaching from chromosome position $56,148,765$ (dbSNP [23], genome build 36.3, rs6567164) 3' of the MC4R to chromosome position 56,247,636 (dbSNP [23], genome build 36.3, rs12966035) $5^{\prime}$ of the gene. SNP selection was performed using HapMap Genome Browser release \#22, phase 2 [24], requiring a minimal observed heterozygosity of $40 \%$ (calculated with Haploview 4.2 [25]). Three SNPs were selected because of their close proximity to the $M C 4 R$ coding region despite a lower expected heterozygosity: rs35748167 (chromosome position 56,188,413; dbSNP [23], genome build 36.3), rs17066842 (chromosome position 56,191,604; dbSNP [23], genome build 36.3), and rs34114122 (chromosome position 56,190,740; dbSNP [23], genome build 36.3). Moreover, another two SNPs, rs17782313 and rs17700633, located $188 \mathrm{~kb}$ (chromosome position 56,002,077; $\mathrm{dbSNP}$ [23], genome build 36.3) and $110 \mathrm{~kb}$ (chromosome position 
Table 1. Descriptive statistics of the 90 obese individuals analyzed

\begin{tabular}{llllll}
\hline Sample & Mutation subgroup & $\begin{array}{l}\text { n total } \\
(\text { female })\end{array}$ & $\begin{array}{l}\text { Median age, years } \\
(\mathrm{Q} 1 ; \mathrm{Q})\end{array}$ & $\begin{array}{l}\text { Median BMI } \\
\text { (Q1; Q3) }\end{array}$ & $\begin{array}{l}\text { Median BMI-SDS } \\
(\mathrm{Q} 1 ; \mathrm{Q} 3)\end{array}$ \\
\hline Obese mutation & total & $62(38)$ & $13.25(11.60 ; 16.80)$ & $31.48(28.05 ; 36.12)$ & $3.49(2.87 ; 4.52)$ \\
carriers & like wild type & $19(12)$ & $13.64(13.05 ; 41.95)$ & $32.49(29.89 ; 35.60)$ & $3.31(2.35 ; 3.67)$ \\
& partial loss of function & $18(12)$ & $11.75(10.92 ; 23.50)$ & $29.06(26.58 ; 33.01)$ & $3.62(2.82 ; 4.13)$ \\
Obese non-carriers & complete loss of function & $25(14)$ & $13.20(9.77 ; 15.32)$ & $31.93(28.81 ; 40.96)$ & $4.41(3.19 ; 6.79)$ \\
& total & $28(22)$ & $16.13(15.30 ; 16.84)$ & $38.50(35.11 ; 43.39)$ & $6.32(4.91 ; 8.85)$ \\
\hline
\end{tabular}

${ }^{a}$ BMI-standard deviation score (BMI-SDS) is a normalized version of BMI expressed as standard deviation score that includes information on age and sex based on a reference population (National Nutrition Survey I).

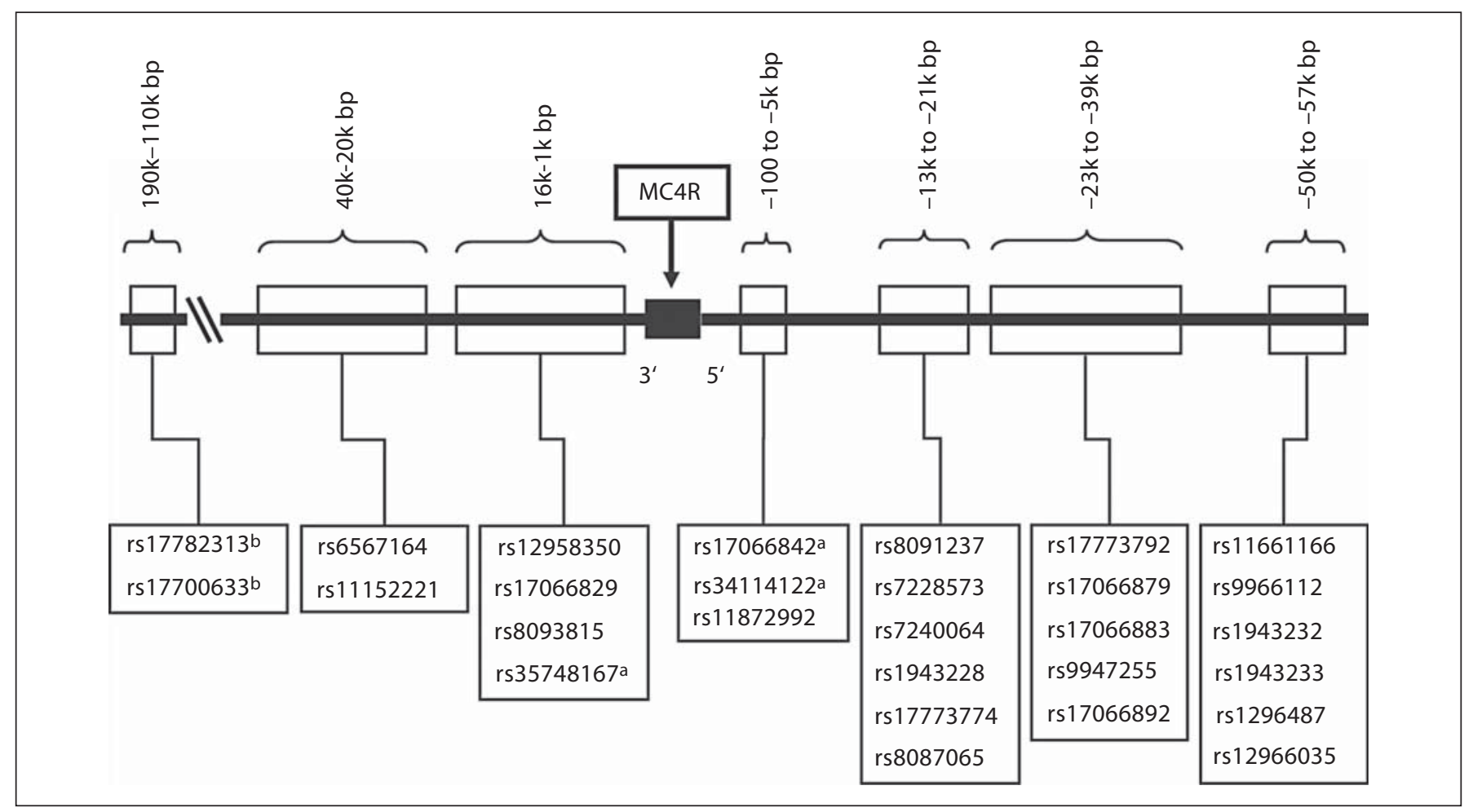

Fig. 1. SNPs that were selected for de novo genotyping and analyses. Their relative physical chromosomal positions in relation to the $M C 4 R$ coding region on chromosome 18q21 are provided in base pairs (bp) according to dbSNP (genome build 36.3). See Methods section for more details. ${ }^{\text {a }}$ SNP included based on proximity to the $M C 4 R$ coding region. ${ }^{b} S N P$ included based on previous reports.

56,080,412; dbSNP [23], genome build 36.3) downstream of MC4R based on previous reports $[3,5,9]$ (fig. 1). For SNP analyses, polymerase chain reaction assays and iPLEX ${ }^{\circledR}$ reaction assays were designed by using the spectroDESIGNER ${ }^{\circledR}$ software (Sequenom Inc., San Diego, Calif., USA). DNA samples of 90 individuals were genotyped using matrix-assisted laser desorption/ionization time-of-flight mass spectrometry (Sequenom Inc.) as described previously [26].
Functional Characterization of MC4R Mutations

Functional characterization was performed for those $M C 4 R$ mutations which were new at the time of detection in the patients (table 2). The genomic DNA of the respective mutated MC4Rs was directly cloned into the eukaryotic expression vector pcDps. For cell surface expression assays, the respective mutated MC4Rs were amplified from genomic DNA using a forward primer containing the Kozak sequence and an N-terminal hemagglutinin 
Table 2. Classification of $M C 4 R$ mutations into three categories, according to own findings and data from literature (as indicated) in the context of cell surface expression and signaling properties in vitro

\begin{tabular}{|c|c|c|}
\hline$M C 4 R$ mutation & Cases, $\mathrm{n}$ & References \\
\hline \multicolumn{3}{|l|}{ (a) Like wild type } \\
\hline p.Thr112Met ${ }^{\mathrm{a}}$ & 10 & $20,43,48-52$ \\
\hline p.Pro230Leu ${ }^{b}$ & 1 & $20,43,53,54$ \\
\hline p.Val95Ile & 1 & 27 \\
\hline p.Met200Val ${ }^{\mathrm{a}}$ & 1 & 48 \\
\hline p.Ala175Thr ${ }^{\mathrm{a}}$ & 2 & $27,43,52$ \\
\hline p.Thr178Met & 1 & 20,43 \\
\hline p.Val166Ile & 1 & 55 \\
\hline p.Pro48Ser ${ }^{a}$ & 1 & 43,56 \\
\hline p.Asn274Ser ${ }^{\mathrm{a}}$ & 1 & $27,43,56$ \\
\hline \multicolumn{3}{|l|}{ (b) Partial loss of function } \\
\hline p.Ile317Thr & 2 & 57,58 \\
\hline p.Arg165Trp ${ }^{b}$ & 2 & 20,43 \\
\hline p.Arg305Gln & 2 & 52 \\
\hline [p.Ser127Leu; p.Val103Ile] ${ }^{\mathrm{a}}$ & 3 & own data, unpubl. \\
\hline p.Ala244Glub & 1 & $20,43,53,57$ \\
\hline p.Ile121Thrb & 1 & 20,59 \\
\hline p.Glu308Lys ${ }^{b}$ & 1 & 59,60 \\
\hline p.Pro275Ser & 2 & own data, unpubl. \\
\hline p.Gly252Ser & 3 & 43,57 \\
\hline p.Met281Val ${ }^{\text {a }}$ & 1 & 22 \\
\hline \multicolumn{3}{|l|}{ (c) Complete loss of function } \\
\hline$\left[\right.$ p.Tyr35Stop; c.110 A>T] ${ }^{a}$ & 17 & $20,43,57$ \\
\hline p.Leu2 $11 \mathrm{fsX} 15^{\mathrm{c}}$ & 4 & 52 \\
\hline [p.Gly181Asp] + [p.Ile251Leu] & 1 & $20,43,50,59$ \\
\hline p.Glu61Stop ${ }^{\mathrm{a}}$ & 1 & 61 \\
\hline p.Leu250fsX34 & 1 & 20 \\
\hline p.Gln307Stop ${ }^{a}$ & 1 & 22 \\
\hline
\end{tabular}

'Cases, $\mathrm{n}$ ' is the available number of samples for each $M C 4 R$ mutation.

a Own functional data available.

$\mathrm{b}$ Divergent functional data in the literature, finally classification according to the predominantly obese phenotype as partial loss of function (see Methods section for more details).

${ }^{c}$ Previous nomenclature: L211fsX216.

d Previous nomenclature: L250fsX284.

(HA) tag after the start codon. These constructs were directly cloned into the eukaryotic expression vector pcDps.

COS-7 cells were maintained in Dulbecco's modified Eagle's medium (Sigma, Deisenhausen, Germany) supplemented with $5 \%$ fetal calf serum and $20 \mathrm{~mm}$ glutamine. Cells were incubated at $37^{\circ} \mathrm{C}$ in humidified air containing $5 \% \mathrm{CO}_{2}$. For all functional assays, COS-7 cells were seeded into 48 -well plates $(2.5 \times 105$ cells/well). Transient transfections with WT and mutant MC4Rs, respectively, were carried out by using Metafectene ${ }^{\circledR}$ (Biontex, Munich, Germany) according to the manufacturer's protocol.

The MC4R is a Gs/adenylyl cyclase coupling G-protein-coupled receptor, therefore in order to characterize receptor signaling properties of the mutated MC4R, cAMP accumulation was measured. For cAMP measurements, 2 days after transfection, cells were incubated for $30 \mathrm{~min}$ at $37^{\circ} \mathrm{C}$ with the endogenous MC4R ligands $\alpha-\mathrm{MSH}$ and $\beta-\mathrm{MSH}$ as well as with the highly potent ligand NDP- $\alpha-\mathrm{MSH}$ respectively. Intracellular cAMP was measured via AlphaScreen ${ }^{\circledR}$ technology (Perkin-Elmer Life Science, Inc., Boston, Mass., USA) as described elsewhere [27]. AlphaScreen measurements were carried out by using a Mithras LB 940 multimode reader (Berthold Technologies, Bad Wildbad, Germany).

For measurement of the cell surface expression, a cell surface ELISA was performed. Therefore, 2 days after transfection with HA-tagged WT and mutant MC4R constructs, cells were fixed with $4 \%$ formaldehyde. After incubation with $1 \mu \mathrm{g} / \mathrm{ml}$ biotin-labeled anti-HA monoclonal antibody (Roche, Mannheim, Germany), bound anti-HA antibodies were detected with streptavidinlabeled peroxidase (Dianova, Hamburg, Germany) as described elsewhere [28]. Colorimetry was accomplished by using an Anthos Reader 2001 (Anthos Labtech Instruments, Salzburg, Austria).

\section{Haplotype Sequence Analyses for Carriers of Two Different} MC4R Mutations

For determination whether individuals who harbor two different $M C 4 R$ mutations are compound heterozygous or whether both mutations are located on a haplotype, we performed familybased analyses where family data were available (for carriers of the MC4R mutations p.Tyr35Stop and p.Asp37Val, p.Gly181Asp and p.Ile251Leu) [19-21, 29-35]. In case of index cases without families (carriers of the MC4R mutations p.Val103Ile and p. Ser127Leu), we performed genetic analysis via TOPO cloning and automatic resequencing according to the manufacturer's protocol (Invitrogen, Carlsbad, Calif., USA).

\section{Classification of the MC4R Mutations}

We classified the $25 M C 4 R$ mutations according to our own functional data and data from literature into three functional categories: (a) 'like wild type' for all variants that do not differ from the WT receptor in cell surface expression and signaling properties in vitro, (b) 'partial loss of function' for MC4R mutations showing partial loss of function, and (c) 'complete loss of function' for MC4R mutations with complete loss of receptor function in vitro (table 2). In the case of the carriers of the two mutations p.Gly181Asp and p.Ile251Leu which emerged to be compound heterozygous [20], functional characterization was performed for each mutation separately. The classification was based on the mutation with the stronger functional effect. In the case of the carriers of the haplotypes [p.Val103Ile; p. Ser127Leu] and [p.Tyr35Stop; c.110 A $>$ T] [19-21, 29-35], functional analyses were performed for the haplotypes. Heterozygous (partial) loss of function $M C 4 R$ mutations with a dominant-negative effect could have a higher functional relevance than complete loss of function mutations. To date, only two MC4R mutations with a dominant-negative effect were described (Asp90Asn [36] and Ser136Phe [37]). As these $M C 4 R$ mutations were not present in this study, dominant-negative effects were not relevant for the classification.

\section{Statistical Analyses}

Initially we screened this region for haplotype combinations containing three SNPs of the 28 SNPs genotyped which discrim- 
inate best (as judged by p value) between obese $M C 4 R$ mutation carriers and obese individuals without mutation in the $M C 4 R$ coding region (neither singles SNPs nor two-SNP haplotypes had smaller $\mathrm{p}$ values). We performed multiple marker combination tests using Monte-Carlo simulations (50,000 simulations) as implemented in FAMHAP (version 18) $[38,39]$ to derive empirical p values and $p$ values adjusted for multiple testing. Afterwards, the three-SNP haplotype combination with the lowest $p$ value was explored in subgroups of the obese mutation carriers according to the mutation classification (a) 'like wild type', (b) 'partial loss of function', and (c) 'loss of function' (table 2). Haplotype frequencies were estimated with and without omitting haplotypes with $\geq 5$ estimated counts in mutation carriers and non-carriers. We performed these analyses in the total sample of all mutation carriers and non-carriers and in 100 random draws each with just one randomly selected case for each MC4R mutation (overall 25 different mutations as displayed in table 2; both omitting or not omitting rare haplotypes - see table 4) to explore so-called 'cryptic relatedness' (i.e., kinship among mutation carriers or non-carriers that is not known to the investigator). In addition, we estimated the proportion of alleles shared identical by state (IBS) in three groups of (1) individuals with the p.Thr112Met mutation $(\mathrm{n}=10)$, in (2) individuals with the [p.Tyr35Stop; c.110 A $>$ T] mutation $(\mathrm{n}=17)$, and (3) in all individuals not belonging to either of these groups $(\mathrm{n}=62)$. We compared each of the groups (1) and (2) to (3) to support the idea of 'cryptic relatedness' using all 28 SNPs by a permutation test.

\section{Results}

\section{Signal Transduction Properties and Functional}

Characterization of the MC4R Mutations

Twenty-five different $M C 4 R$ mutations were included into statistical calculations and differentiated in the context of their relevance for receptor function. The function was represented by signaling properties in vitro. Carriers of the two mutations p.Gly181Asp and p.Ile251Leu emerged to be compound heterozygous [20] and the mutations p.Val103Ile, p. Ser127Leu and p.Tyr35Stop, p.Asp37Val formed a haplotype in all analyzed carriers as shown previously [19-21, 29-35].

We formed three categories (a) 'like wild type', (b) 'partial loss of function', and (c) 'complete loss of function', according to data from literature and own experiments (13 cases, table 2 ). In case of diverging characterizations of 'partial loss of function' and 'like wild type' between literature and own data (6 cases, table 2 ), our classification was first guided by the predominant grouping. If the data still remained ambiguous, we considered own data and finally evolutionary aspects like the degree of conservation of the respective amino acid. In the case of a highly conserved amino acid, we determined the category as 'partial loss of function'. The compound hetero- zygous carrier of the two mutations p.Gly181Asp and p.Ile251Leu was classified according to the functional characterization of p.Gly181Asp ('loss of function'). This classification is supported by the fact that the p.Ile251Leu has a protective effect against obesity [40] but there is no solid evidence yet that the p.Ile251Leu affects receptor signaling [41-43].

Finally, 9 mutations (19 obese patients) were assigned to 'like wild type', 10 mutations (18 obese patients) to 'partial loss of function', and $6 M C 4 R$ mutations (25 patients) were assigned to the category 'complete loss of function' (table 2).

\section{Haplotype Analyses}

The analyses revealed a set of three SNP (rs17782313, rs12958350, rs17066829) downstream of the coding region of the $M C 4 R$ that discriminates best between obese $M C 4 R$ mutation carriers and obese non $M C 4 R$ mutation carriers (estimated $\mathrm{p}<0.0001-0$ out of 50,000 MonteCarlo simulations lead to more extreme results; table 3). This marker combination was next explored for the three categories of MC4R mutations (a) 'like wild type', (b) 'partial loss of function', and (c) 'complete loss of function'. These analyses in the different categories suggested that the overall effect is most likely due to $M C 4 R$ mutations which result in a complete loss of function $(\mathrm{p}=0.001$; table 3). Next, we explored the corresponding haplotypes and their frequencies. In all individuals, the largest discrepancy in haplotype frequencies was observed for the haplotype CGA (for the SNPs rs17782313, rs12958350, rs17066829) with an estimated frequency of $27.6 \%$ in obese $M C 4 R$ mutation carriers and $0.7 \%$ in obese $M C 4 R$ mutation-free controls. This difference was similarly present in the category 'complete loss of function' $(31.9 \%$ in obese $M C 4 R$ mutation carriers vs. $1.7 \%$ in obese without MC4R mutation).

Next, we explored the robustness of our finding in sensitivity analyses addressing 'cryptic relatedness' as individuals with the same infrequent mutation might be remotely related (the patients and the investigators not being aware of their relationship). We used just one randomly selected case for each MC4R mutation (overall 25 different mutations as displayed in table 2), performed the same analyses as before and repeated this procedure 100 times (100 random draws). The impact on the $p$ value distributions is shown in table 4. Moreover, we observed no strong or moderate Spearman correlations (all $\rho$ between -0.3 and 0.3 ) between the results indicating no direct relationship between the overall results and the findings in the categories. Irrespective of omitting or not 
Table 3. The three-SNP haplotype combination and the corresponding haplotypes discriminating best between obese individuals with $M C 4 R$ mutation and obese individuals without MC4R mutation

\begin{tabular}{|c|c|c|c|c|}
\hline Group comparison & $\begin{array}{l}\text { Haplotype } \\
\text { (rs17782313 } \\
\text { rs12958350 } \\
\text { rs17066829) }\end{array}$ & $\begin{array}{l}\text { Estimated } \\
\text { frequency } \\
\text { in cases }\end{array}$ & $\begin{array}{l}\text { Estimated } \\
\text { frequency } \\
\text { in controls }\end{array}$ & $\mathrm{p}$ value \\
\hline $\begin{array}{l}\text { All mutation } \\
\text { carriers vs. non-carriers }\end{array}$ & $\begin{array}{l}\text { C G A } \\
\text { T G T } \\
\text { T A T } \\
\text { C A T } \\
\text { T G A } \\
\text { C G T } \\
\text { C A A } \\
\text { T A A }\end{array}$ & $\begin{array}{l}0.276 \\
0.285 \\
0.188 \\
0.027 \\
0.081 \\
0.027 \\
0.027 \\
0.089\end{array}$ & $\begin{array}{l}0.007 \\
0.353 \\
0.127 \\
0.080 \\
0.100 \\
0.140 \\
0.153 \\
0.040\end{array}$ & $\begin{array}{l}<0.0001 \\
(0.006 \text { when adjusted } \\
\text { for multiple testing) }\end{array}$ \\
\hline $\begin{array}{l}\text { (a) Like wild type: } \\
\text { mutation carriers vs. non-carriers }\end{array}$ & $\begin{array}{l}\text { T G T } \\
\text { T G A } \\
\text { C G T } \\
\text { T A T } \\
\text { T A A } \\
\text { C A A }\end{array}$ & $\begin{array}{l}0.385 \\
0.195 \\
0.030 \\
0.109 \\
0.124 \\
0.103\end{array}$ & $\begin{array}{l}0.363 \\
0.090 \\
0.143 \\
0.126 \\
0.040 \\
0.166\end{array}$ & 0.201 \\
\hline $\begin{array}{l}\text { (b) Partial loss of function: } \\
\text { mutation carriers vs. non-carriers }\end{array}$ & $\begin{array}{l}\text { T A T } \\
\text { T G T } \\
\text { T G A } \\
\text { C A A } \\
\text { C G A }\end{array}$ & $\begin{array}{l}0.298 \\
0.272 \\
0.062 \\
0.111 \\
0.081\end{array}$ & $\begin{array}{l}0.130 \\
0.360 \\
0.092 \\
0.166 \\
0.143\end{array}$ & 0.353 \\
\hline $\begin{array}{l}\text { (c) Complete loss of function: } \\
\text { mutation carriers vs. non-carriers }\end{array}$ & $\begin{array}{l}\text { C G A } \\
\text { T G T } \\
\text { C A A } \\
\text { C G T } \\
\text { T A T } \\
\text { T G A }\end{array}$ & $\begin{array}{l}0.319 \\
0.269 \\
0.104 \\
0.087 \\
0.050 \\
0.137\end{array}$ & $\begin{array}{l}0.017 \\
0.353 \\
0.156 \\
0.136 \\
0.141 \\
0.094\end{array}$ & 0.001 \\
\hline
\end{tabular}

Only haplotypes with $\geq 5$ counts in mutation carriers and non-carriers were concerned. Additionally, the best three-SNP haplotype combination was checked for its effects on the three categories of mutation carriers based on the mutation classification shown in table 2 .

omitting rare haplotypes (see section Statistical Analyses), we found no evidence for group differences.

Finally, we compared the median proportions of all alleles shared identity by state (IBS) for all 28 SNP and all pairwise comparisons among all 10 p.Thr112Met mutation carriers, among all 17 [p.Tyr35Stop; c.110 A>T] mutation carriers and among all 62 individuals not belonging to either of these groups. For the 10 p.Thr112Met mutation carriers the medians proportions for the IBS states $(0 ; 1 ; 2)$ were $(0.00 ; 0.68 ; 0.09)$, for the 17 [p.Tyr35Stop; c. $110 \mathrm{~A}>\mathrm{T}]$ mutation carriers they were $(0.00 ; 0.68 ; 0.04)$ and $(0.45 ; 0.30 ; 0.00)$ for the 62 individuals not belonging to these groups. Running two permutation tests for each of the groups with carriers of the same mutations also indicated that they are similar to each other as compared to the 62 individuals, also underlining the closer relationship within the groups of carriers of the same mutations (both $\mathrm{p}<0.01$ ).

\section{Discussion}

We aimed to detect SNP alleles or haplotypes which co-segregate with $M C 4 R$ mutations. Ultimately, if truly existent, such a haplotype would be a first step towards an enrichment procedure for clinical practice to more easily detect MC4R mutations in obese patients. 
Table 4. The impact of choosing just 1 randomly selected case for each $M C 4 R$ mutation (100 times) on the p value distributions for either omitting or not omitting rare haplotypes (for a definition see Methods section)

\begin{tabular}{lll}
\hline Group comparison & \multicolumn{2}{l}{$\begin{array}{l}\text { p value distribution } \\
\text { (min., 1st, 2nd, 3rd quartile, max.) }\end{array}$} \\
\cline { 2 - 3 } & $\begin{array}{l}\text { without rare } \\
\text { haplotypes }\end{array}$ & $\begin{array}{l}\text { with rare } \\
\text { haplotypes }\end{array}$ \\
\hline All mutation carriers vs. & 0.03 & 0.05 \\
non-carriers & 0.08 & 0.10 \\
& 0.13 & 0.14 \\
& 0.29 & 0.18 \\
(a) Like wild type: & 0.64 & 0.36 \\
mutation carriers & 0.08 & 0.05 \\
vs. non-carriers & 0.15 & 0.07 \\
& 0.16 & 0.08 \\
& 0.29 & 0.14 \\
(b) Partial loss of function: & 0.15 & 0.16 \\
mutation carriers vs. & 0.36 & 0.07 \\
non-carriers & 0.65 & 0.36 \\
& 0.94 & 0.62 \\
& 0.99 & 0.94 \\
(c) Complete loss of & 0.54 & 0.00 \\
function: mutation & 0.81 & 0.06 \\
carriers vs. non-carriers & 0.89 & 0.31 \\
& 0.97 & 0.39 \\
\hline
\end{tabular}

We identified a triplet of SNP alleles (rs17782313, rs12958350, rs17066829 [C; G; A]) which discriminated best between all obese mutation carriers and obese nonmutation carriers. SNP rs17782313 which showed a robustly replicated association with obesity in several studies $[3,5,9]$ is included in this haplotype combination. Subsequent analyses by mutation categories showed that the overall effect was largely due to an effect for the category c) 'complete loss of function'.

However, this observation is debatable. First, functional characterization represents a general problem in mutation classification (i) because obesity is a highly polygenic trait variation [44] and for melanocortin receptors a higher rate of naturally occurring mutations is known for which no significant effect on receptor function could be detected [45] compared to mutations in other G-protein-coupled receptors, and (ii) because of discrepancies between the situations in vitro and in vivo. In case of the $M C 4 R$ the applied cell systems in vitro differ from the physiological reality and are mostly characterized by overexpression of the receptor. Different readout systems are used and have different sensitivities. This could lead to additional discrepancies and could account for divergent results in receptor function throughout literature. Furthermore, MC4R mutations causing dominant-negative effects seem to be rare $[35,37,46]$. The mutation [p.Tyr35Stop; c.110 A>T] is suggested to lead to haploinsufficiency because the short truncated protein is presumed to be rapidly degraded upon translation [32, 35]. The quantitative difference between carriers of the $\mathrm{WT}$ allele and the [p.Tyr35Stop; c.110 A>T] in BMI is rather low compared to other $M C 4 R$ missense mutation carriers [35]. Nevertheless, this may be due to the fact that the nonsense mutation is rapidly degraded and thereby cannot affect the function of other proteins which might be the case for a missense mutation within the $M C 4 R$.

Second, 'cryptic relatedness' had a large impact on our findings which had previously been shown for classical genetic case-control studies of complex traits [47]. When re-running our analysis but only including one patient per mutation, we could not confirm our initial results. This apparent discrepancy was due to a majority of 'complete loss of function' mutation carriers being of the p.[Tyr35Stop; c. $110 \mathrm{~A}>\mathrm{T}$ ] type (17 of 25 individuals in this category). For these 17 carriers a distant relationship is very likely and has been supported by our IBS analysis and has also previously been suggested [19,32]. Moreover, our analysis also indicated evidence for 'cryptic relatedness' between the 10 p.Thr112Met mutation carriers.

Third, our analysis is limited by the number of patients genotyped and characterized for mutations. Limiting our analysis to just one patient per mutation of course further adds to this sample size constraint. However, given our study design, obese individuals with MC4R mutations need to be identified and functionally characterized. One should take into consideration that the access to a large cohort is a prerequisite for the availability of a sufficiently large number of well-characterized $M C 4 R$ mutation carriers (given an estimated $M C 4 R$ mutation rate of $1-5 \%$ in obese individuals $[21,31])$. Having access to such a large number of mutation carriers represent, after all, a unique feature of our study.

For another study design, focusing on individuals from GWAS samples, it has recently been shown that common variants both up- and downstream of the MC4R coding region show an obesogenic effect [15]. Removing individuals with a known functionally relevant $M C 4 R$ mutation had little or no impact on the findings, thus contradicting the idea of a 'synthetic association' at the MC4R [38]. 
In sum, we first observed evidence for a haplotype of SNP alleles downstream of the $M C 4 R$ which discriminated between obese MC4R mutation carriers and obese non-mutation carriers. Although a replication effort of our data is absolutely necessary, upon closer examination our findings were most likely due to 'cryptic relatedness' effects between carriers of the same mutation. Our data underscore challenges that do arise when common SNP variants and mutations are analyzed jointly in a wellcharacterized but small study. However, our findings are of great relevance even for much larger sample sizes whenever SNP information from GWAS is linked to rare variant resequencing data.

\section{Acknowledgements}

This work was supported by the Deutsche Forschungsgesellschaft (DFG): Graduate College 1208 TP1, and by the Bundesministerium für Bildung und Forschung 01KU0903 and NGFNplus 01GS0820, 01GS0822, 01GS0825. The European Community's Seventh Framework Programme (FP7/2007-2013) under grant agreement No. 245009 supported this study.

\section{Disclosure Statement}

The authors have no conflicts of interest to disclose.

\section{References}

1 Hindorff L, Junkins H, Manolio T: NHGRI catalog of published genome-wide association studies. http://wwwgenomegov/ gwastudies (2010).

-2 Hindorff LA, Sethupathy P, Junkins HA, Ramos EM, Mehta JP, Collins FS, Manolio TA: Potential etiologic and functional implications of genome-wide association loci for human diseases and traits. Proc Natl Acad Sci USA 2009; 106:9362-9367.

3 Speliotes EK, Willer CJ, Berndt SI, Monda KL, Thorleifsson G, Jackson AU, Allen HL, Lindgren CM, Luan J, Magi R, Randall JC, Vedantam S, Winkler TW, Qi L, Workalemahu T, Heid IM, Steinthorsdottir V, Stringham HM, Weedon MN, Wheeler E, Wood AR, Ferreira T, Weyant RJ, Segre AV, Estrada K, Liang L, Nemesh J, Park JH, Gustafsson S, Kilpelainen TO, Yang J, BouatiaNaji N, Esko T, Feitosa MF, Kutalik Z, Mangino M, Raychaudhuri S, Scherag A, Smith AV, Welch R, Zhao JH, Aben KK, Absher DM, Amin N, Dixon AL, Fisher E, Glazer NL, Goddard ME, Heard-Costa NL, Hoesel V, Hottenga JJ, Johansson A, Johnson T, Ketkar S, Lamina C, Li S, Moffatt MF, Myers RH, Narisu N, Perry JR, Peters MJ, Preuss M, Ripatti S, Rivadeneira F, Sandholt C, Scott LJ, Timpson NJ, Tyrer JP, van Wingerden S, Watanabe RM, White CC, Wiklund F, Barlassina C, Chasman DI, Cooper MN, Jansson JO, Lawrence RW, Pellikka N, Prokopenko I, Shi J, Thiering E, Alavere H, Alibrandi MT, Almgren P, Arnold AM, Aspelund T, Atwood LD, Balkau B, Balmforth AJ, Bennett AJ, Ben-Shlomo Y, Bergman RN, Bergmann S, Biebermann H, Blakemore AI, Boes T, Bonnycastle LL, Bornstein SR, Brown MJ, Buchanan TA, Busonero F, Campbell H, Cappuccio FP, Cavalcanti-Proenca C, Chen YD, Chen CM, Chines PS, Clarke R, Coin L, Connell J, Day IN, Heijer MD, Duan J, Ebrahim S, Elliott P, Elosua R,
Eiriksdottir G, Erdos MR, Eriksson JG, Facheris MF, Felix SB, Fischer-Posovszky P, Folsom AR, Friedrich N, Freimer NB, Fu M, Gaget S, Gejman PV, Geus EJ, Gieger C, Gjesing AP, Goel A, Goyette P, Grallert H, Grassler J, Greenawalt DM, Groves CJ, Gudnason V, Guiducci C, Hartikainen AL, Hassanali N, Hall AS, Havulinna AS, Hayward C, Heath AC, Hengstenberg C, Hicks AA, Hinney A, Hofman A, Homuth G, Hui J, Igl $\mathrm{W}$, Iribarren C, Isomaa B, Jacobs KB, Jarick I, Jewell E, John U, Jorgensen T, Jousilahti P, Jula A, Kaakinen M, Kajantie E, Kaplan LM, Kathiresan S, Kettunen J, Kinnunen L, Knowles JW, Kolcic I, Konig IR, Koskinen S, Kovacs P, Kuusisto J, Kraft P, Kvaloy K, Laitinen J, Lantieri O, Lanzani C, Launer LJ, Lecoeur C, Lehtimaki T, Lettre G, Liu J, Lokki ML, Lorentzon M, Luben RN, Ludwig B, Manunta P, Marek D, Marre M, Martin NG, McArdle WL, McCarthy A, McKnight B, Meitinger T, Melander O, Meyre D, Midthjell K, Montgomery GW, Morken MA, Morris AP, Mulic R, Ngwa JS, Nelis M, Neville MJ, Nyholt DR, O'Donnell CJ, O'Rahilly S, Ong KK, Oostra B, Pare G, Parker AN, Perola M, Pichler I, Pietilainen KH, Platou CG, Polasek O, Pouta A, Rafelt S, Raitakari O, Rayner NW, Ridderstrale M, Rief W, Ruokonen A, Robertson NR, Rzehak P, Salomaa V, Sanders AR, Sandhu MS, Sanna S, Saramies J, Savolainen MJ, Scherag S, Schipf S, Schreiber S, Schunkert H, Silander K, Sinisalo J, Siscovick DS, Smit JH, Soranzo N, Sovio U, Stephens J, Surakka I, Swift AJ, Tammesoo ML, Tardif JC, Teder-Laving M, Teslovich TM, Thompson JR, Thomson B, Tonjes A, Tuomi T, van Meurs JB, van Ommen GJ, Vatin V, Viikari J, Visvikis-Siest S, Vitart V, Vogel CI, Voight BF, Waite LL, Wallaschofski H, Walters GB, Widen E, Wiegand S, Wild SH, Willemsen G, Witte DR, Witteman JC, Xu J, Zhang Q, Zgaga L, Ziegler A, Zitting P, Beil- by JP, Farooqi IS, Hebebrand J, Huikuri HV, James AL, Kahonen M, Levinson DF, Macciardi F, Nieminen MS, Ohlsson C, Palmer LJ, Ridker PM, Stumvoll M, Beckmann JS, Boeing $\mathrm{H}$, Boerwinkle E, Boomsma DI, Caulfield MJ, Chanock SJ, Collins FS, Cupples LA, Smith GD, Erdmann J, Froguel P, Gronberg H, Gyllensten U, Hall P, Hansen T, Harris TB, Hattersley AT, Hayes RB, Heinrich J, Hu FB, Hveem K, Illig T, Jarvelin MR, Kaprio J, Karpe F, Khaw KT, Kiemeney LA, Krude H, Laakso M, Lawlor DA, Metspalu A, Munroe PB, Ouwehand WH, Pedersen O, Penninx BW, Peters A, Pramstaller PP, Quertermous T, Reinehr T, Rissanen A, Rudan I, Samani NJ, Schwarz PE, Shuldiner AR, Spector TD, Tuomilehto J, Uda M, Uitterlinden A, Valle TT, Wabitsch M, Waeber G, Wareham NJ, Watkins $H$, Wilson JF, Wright AF, Zillikens MC, Chatterjee N, McCarroll SA, Purcell S, Schadt EE, Visscher PM, Assimes TL, Borecki IB, Deloukas P, Fox CS, Groop LC, Haritunians T, Hunter DJ, Kaplan RC, Mohlke KL, O'Connell JR, Peltonen L, Schlessinger D, Strachan DP, van Duijn CM, Wichmann HE, Frayling TM, Thorsteinsdottir U, Abecasis GR, Barroso I, Boehnke M, Stefansson K, North KE, M IM, Hirschhorn JN, Ingelsson E, Loos RJ: Association analyses of 249,796 individuals reveal 18 new loci associated with body mass index. Nat Genet 2010;42:937-948.

-4 Scuteri A, Sanna S, Chen WM, Uda M, Albai G, Strait J, Najjar S, Nagaraja R, Orru M, Usala G, Dei M, Lai S, Maschio A, Busonero F, Mulas A, Ehret GB, Fink AA, Weder AB, Cooper RS, Galan P, Chakravarti A, Schlessinger D, Cao A, Lakatta E, Abecasis GR: Genome-wide association scan shows genetic variants in the FTO gene are associated with obesity-related traits. PLoS Genet 2007; 3:e115. 
5 Hinney A, Nguyen TT, Scherag A, Friedel S, Bronner G, Muller TD, Grallert H, Illig T, Wichmann HE, Rief W, Schafer H, Hebebrand J: Genome wide association (GWA) study for early onset extreme obesity supports the role of fat mass and obesity associated gene (FTO) variants. PLoS One 2007; 2:e1361.

6 Frayling TM, Timpson NJ, Weedon MN, Zeggini E, Freathy RM, Lindgren CM, Perry JR, Elliott KS, Lango H, Rayner NW, Shields B, Harries LW, Barrett JC, Ellard S, Groves CJ, Knight B, Patch AM, Ness AR, Ebrahim S, Lawlor DA, Ring SM, Ben-Shlomo Y, Jarvelin MR, Sovio U, Bennett AJ, Melzer D, Ferrucci L, Loos RJ, Barroso I, Wareham NJ, Karpe F, Owen KR, Cardon LR, Walker M, Hitman GA, Palmer CN, Doney AS, Morris AD, Smith GD, Hattersley AT, McCarthy MI: A common variant in the FTO gene is associated with body mass index and predisposes to childhood and adult obesity. Science 2007:316:889-894.

7 Thorleifsson G, Walters GB, Gudbjartsson DF, Steinthorsdottir V, Sulem P, Helgadottir A, Styrkarsdottir U, Gretarsdottir S, Thorlacius $\mathrm{S}$, Jonsdottir I, Jonsdottir T, Olafsdottir EJ, Olafsdottir GH, Jonsson T, Jonsson F, Borch-Johnsen K, Hansen T, Andersen G, Jorgensen T, Lauritzen T, Aben KK, Verbeek AL, Roeleveld N, Kampman E, Yanek LR, Becker LC, Tryggvadottir L, Rafnar T, Becker DM, Gulcher J, Kiemeney LA, Pedersen O, Kong A, Thorsteinsdottir U, Stefansson K: Genome-wide association yields new sequence variants at seven loci that associate with measures of obesity. Nat Genet 2009;41: $18-24$.

8 Willer CJ, Speliotes EK, Loos RJ, Li S, Lindgren CM, Heid IM, Berndt SI, Elliott AL, Jackson AU, Lamina C, Lettre G, Lim N, Lyon HN, McCarroll SA, Papadakis K, Qi L, Randall JC, Roccasecca RM, Sanna S, Scheet P, Weedon MN, Wheeler E, Zhao JH, Jacobs LC, Prokopenko I, Soranzo N, Tanaka T, Timpson NJ, Almgren P, Bennett A, Bergman RN, Bingham SA, Bonnycastle LL, Brown M, Burtt NP, Chines P, Coin L, Collins FS, Connell JM, Cooper C, Smith GD, Dennison EM, Deodhar P, Elliott P, Erdos MR, Estrada K, Evans DM, Gianniny L, Gieger C, Gillson CJ, Guiducci C, Hackett R, Hadley D, Hall AS, Havulinna AS, Hebebrand $J$, Hofman A, Isomaa $B$, Jacobs $K B$, Johnson T, Jousilahti P, Jovanovic Z, Khaw KT, Kraft P, Kuokkanen M, Kuusisto J, Laitinen J, Lakatta EG, Luan J, Luben RN, Mangino $\mathrm{M}$, McArdle WL, Meitinger T, Mulas A, Munroe PB, Narisu N, Ness AR, Northstone K, O'Rahilly S, Purmann C, Rees MG, Ridderstrale M, Ring SM, Rivadeneira F, Ruokonen A, Sandhu MS, Saramies J, Scott LJ, Scuteri A, Silander K, Sims MA, Song K, Stephens J, Stevens S, Stringham HM, Tung YC, Valle TT, Van Duijn CM, Vimaleswaran KS, Vollenweider P, Waeber G, Wallace C, Watanabe RM, Waterworth DM,
Watkins N, Witteman JC, Zeggini E, Zhai G, Zillikens MC, Altshuler D, Caulfield MJ, Chanock SJ, Farooqi IS, Ferrucci L, Guralnik JM, Hattersley AT, Hu FB, Jarvelin MR, Laakso M, Mooser V, Ong KK, Ouwehand WH, Salomaa V, Samani NJ, Spector TD, Tuomi T, Tuomilehto J, Uda M, Uitterlinden AG, Wareham NJ, Deloukas P, Frayling TM, Groop LC, Hayes RB, Hunter DJ, Mohlke KL, Peltonen L, Schlessinger D, Strachan DP, Wichmann HE, McCarthy MI, Boehnke M, Barroso I, Abecasis GR, Hirschhorn JN: Six new loci associated with body mass index highlight a neuronal influence on body weight regulation. Nat Genet 2009;41:25-34.

-9 Loos RJ, Lindgren CM, Li S, Wheeler E, Zhao JH, Prokopenko I, Inouye M, Freathy RM, Attwood AP, Beckmann JS, Berndt SI, Jacobs KB, Chanock SJ, Hayes RB, Bergmann S, Bennett AJ, Bingham SA, Bochud M, Brown M, Cauchi S, Connell JM, Cooper C, Smith GD, Day I, Dina C, De S, Dermitzakis ET, Doney AS, Elliott KS, Elliott P, Evans DM, Sadaf Farooqi I, Froguel P, Ghori J, Groves CJ, Gwilliam R, Hadley D, Hall AS, Hattersley AT, Hebebrand J, Heid IM, Lamina C, Gieger C, Illig T, Meitinger T, Wichmann HE, Herrera B, Hinney A, Hunt SE, Jarvelin MR, Johnson T, Jolley JD, Karpe F, Keniry A, Khaw KT, Luben RN, Mangino M, Marchini J, McArdle WL, McGinnis R, Meyre D, Munroe $\mathrm{PB}$, Morris AD, Ness AR, Neville MJ, Nica AC, Ong KK, O'Rahilly S, Owen KR, Palmer CN, Papadakis K, Potter S, Pouta A, Qi L, Randall JC, Rayner NW, Ring SM, Sandhu MS, Scherag A, Sims MA, Song K, Soranzo N, Speliotes EK, Syddall HE, Teichmann SA, Timpson NJ, Tobias JH, Uda M, Vogel CI, Wallace C, Waterworth DM, Weedon MN, Willer CJ, Wraight, Yuan X, Zeggini E, Hirschhorn JN, Strachan DP, Ouwehand WH, Caulfield MJ, Samani NJ, Frayling TM, Vollenweider P, Waeber G, Mooser V, Deloukas P, McCarthy MI, Wareham NJ, Barroso I, Kraft P, Hankinson SE, Hunter DJ, Hu FB, Lyon HN, Voight BF, Ridderstrale M, Groop L, Scheet P, Sanna S, Abecasis GR, Albai G, Nagaraja R, Schlessinger D, Jackson AU, Tuomilehto J, Collins FS, Boehnke M, Mohlke KL: Common variants near MC4R are associated with fat mass, weight and risk of obesity. Nat Genet 2008;40:768-775.

10 Chambers JC, Elliott P, Zabaneh D, Zhang W, Li Y, Froguel P, Balding D, Scott J, Kooner JS: Common genetic variation near MC4R is associated with waist circumference and insulin resistance. Nat Genet 2008;40:716718.

11 Meyre D, Delplanque J, Chevre JC, Lecoeur C, Lobbens S, Gallina S, Durand E, Vatin V, Degraeve F, Proenca C, Gaget S, Korner A, Kovacs P, Kiess W, Tichet J, Marre M, Hartikainen AL, Horber F, Potoczna N, Hercberg S, Levy-Marchal C, Pattou F, Heude B, Tauber M, McCarthy MI, Blakemore AI, Montpetit A, Polychronakos C, Weill J, Coin LJ, Asher J, Elliott P, Jarvelin MR, Visvikis-Siest
S, Balkau B, Sladek R, Balding D, Walley A, Dina C, Froguel P: Genome-wide association study for early-onset and morbid adult obesity identifies three new risk loci in european populations. Nat Genet 2009;41:157-159.

12 Scherag A, Dina C, Hinney A, Vatin V, Scherag S, Vogel CI, Muller TD, Grallert H, Wichmann HE, Balkau B, Heude B, Jarvelin MR, Hartikainen AL, Levy-Marchal C, Weill J, Delplanque J, Korner A, Kiess W, Kovacs P, Rayner NW, Prokopenko I, McCarthy MI, Schafer H, Jarick I, Boeing H, Fisher E, Reinehr T, Heinrich J, Rzehak P, Berdel D, Borte M, Biebermann H, Krude H, Rosskopf D, Rimmbach C, Rief W, Fromme T, Klingenspor M, Schurmann A, Schulz N, Nothen MM, Muhleisen TW, Erbel R, Jockel KH, Moebus S, Boes T, Illig T, Froguel P, Hebebrand J, Meyre D: Two new loci for bodyweight regulation identified in a joint analysis of genome-wide association studies for early-onset extreme obesity in French and German study groups. PLoS Genet 2010; 6:e1000916.

13 O'Rahilly S, Farooqi IS: Human obesity as a heritable disorder of the central control of energy balance. Int J Obes (Lond) 2008; 32(suppl 7):S55-S61.

14 Tao YX: The melanocortin-4 receptor: physiology, pharmacology, and pathophysiology. Endocr Rev 2010;31:506-543.

15 Scherag A, Jarick I, Grothe J, Biebermann H, Scherag S, Volckmar AL, Vogel CI, Greene B, Hebebrand J, Hinney A: Investigation of a genome-wide association signal for obesity: synthetic association and haplotype analyses at the melanocortin-4 receptor gene locus. PLoS One 2010;5:e13967.

16 Hughes D, Wallace A, Taylor J, Tassabehji M, McMahon R, Hill A, Nevin N, Graham C: Fluorescent multiplex microsatellites used to define haplotypes associated with 75 CFTR mutations from the UK on $437 \mathrm{CF}$ chromosomes. Hum Mutat 1996;8:229-235.

17 Elce A, Boccia A, Cardillo G, Giordano S, Tomaiuolo R, Paolella G, Castaldo G: Three novel CFTR polymorphic repeats improve segregation analysis for cystic fibrosis. Clin Chem 2009;55:1372-1379.

18 Borras E, Pineda M, Blanco I, Jewett EM, Wang F, Teule A, Caldes T, Urioste M, Martinez-Bouzas C, Brunet J, Balmana J, Torres A, Ramon y Cajal T, Sanz J, Perez-Cabornero L, Castellvi-Bel S, Alonso A, Lanas A, Gonzalez S, Moreno V, Gruber SB, Rosenberg NA, Mukherjee B, Lazaro C, Capella G: MLH1 founder mutations with moderate penetrance in Spanish Lynch syndrome families. Cancer Res 2010;70:7379-7391. 
$\checkmark 19$ Hinney A, Schmidt A, Nottebom K, Heibult O, Becker I, Ziegler A, Gerber G, Sina M, Gorg T, Mayer H, Siegfried W, Fichter M, Remschmidt H, Hebebrand J: Several mutations in the melanocortin-4 receptor gene including a nonsense and a frameshift mutation associated with dominantly inherited obesity in humans. J Clin Endocrinol Metab 1999;84:1483-1486.

20 Hinney A, Hohmann S, Geller F, Vogel C, Hess C, Wermter AK, Brokamp B, Goldschmidt H, Siegfried W, Remschmidt H, Schafer H, Gudermann T, Hebebrand J: Melanocortin-4 receptor gene: case-control study and transmission disequilibrium test confirm that functionally relevant mutations are compatible with a major gene effect for extreme obesity. J Clin Endocrinol Metab 2003;88:4258-4267.

-21 Hinney A, Bettecken T, Tarnow P, Brumm H, Reichwald K, Lichtner P, Scherag A, Nguyen TT, Schlumberger P, Rief W, Vollmert C, Illig T, Wichmann HE, Schafer H, Platzer M, Biebermann H, Meitinger T, Hebebrand J: Prevalence, spectrum, and functional characterization of melanocortin-4 receptor gene mutations in a representative populationbased sample and obese adults from Germany. J Clin Endocrinol Metab 2006;91:17611769.

-22 Reinehr T, Hebebrand J, Friedel S, Toschke AM, Brumm H, Biebermann H, Hinney A: Lifestyle intervention in obese children with variations in the melanocortin-4 receptor gene. Obesity (Silver Spring) 2009;17:382389.

-23 Sherry ST, Ward MH, Kholodov M, Baker J, Phan L, Smigielski EM, Sirotkin K: DBSNP: the NCBI database of genetic variation. $\mathrm{Nu}-$ cleic Acids Res 2001;29:308-311.

24 The International HapMap Project: The International HapMap Project. Nature 2003; 426:789-796.

25 Barrett JC, Fry B, Maller J, Daly MJ: Haploview: analysis and visualization of $L D$ and haplotype maps. Bioinformatics 2005;21: 263-265.

-26 Schedel M, Carr D, Klopp N, Woitsch B, Illig T, Stachel D, Schmid I, Fritzsch C, Weiland SK, von Mutius E, Kabesch M: A signal transducer and activator of transcription 6 haplotype influences the regulation of serum IgE levels. J Allergy Clin Immunol 2004; 114:1100-1105.

-27 Staubert C, Tarnow P, Brumm H, Pitra C, Gudermann T, Gruters A, Schoneberg T, Biebermann H, Rompler H: Evolutionary aspects in evaluating mutations in the melanocortin-4 receptor. Endocrinology 2007; 148: 4642-4648.

-28 Schoneberg T, Yun J, Wenkert D, Wess J: Functional rescue of mutant $\mathrm{V} 2$ vasopressin receptors causing nephrogenic diabetes insipidus by a co-expressed receptor polypeptide. EMBO J 1996;15:1283-1291.
29 Lubrano-Berthelier C, Dubern B, Lacorte JM, Picard F, Shapiro A, Zhang S, Bertrais S, Hercberg S, Basdevant A, Clement K, Vaisse C: Melanocortin- 4 receptor mutations in a large cohort of severely obese adults: prevalence, functional classification, genotypephenotype relationship, and lack of association with binge eating. J Clin Endocrinol Metab 2006;91:1811-1818.

30 Stutzmann F, Tan K, Vatin V, Dina C, Jouret B, Tichet J, Balkau B, Potoczna N, Horber F, O’Rahilly S, Farooqi IS, Froguel P, Meyre D: Prevalence of melanocortin-4 receptor deficiency in Europeans and their age-dependent penetrance in multigenerational pedigrees. Diabetes 2008;57:2511-2518.

-31 Farooqi IS, Keogh JM, Yeo GS, Lank EJ, Cheetham T, O'Rahilly S: Clinical spectrum of obesity and mutations in the melanocortin-4 receptor gene. N Engl J Med 2003;348: 1085-1095.

32 Larsen LH, Echwald SM, Sorensen TI, Andersen T, Wulff BS, Pedersen O: Prevalence of mutations and functional analyses of melanocortin-4 receptor variants identified among 750 men with juvenile-onset obesity. J Clin Endocrinol Metab 2005;90:219-224.

33 Hebebrand J, Geller F, Dempfle A, HeinzelGutenbrunner M, Raab M, Gerber G, Wermter AK, Horro FF, Blundell J, Schafer H, Remschmidt $\mathrm{H}$, Herpertz S, Hinney A: Binge-eating episodes are not characteristic of carriers of melanocortin-4 receptor gene mutations. Mol Psychiatry 2004;9:796-800.

-34 Sina M, Hinney A, Ziegler A, Neupert T, Mayer H, Siegfried W, Blum WF, Remschmidt $\mathrm{H}$, Hebebrand J: Phenotypes in three pedigrees with autosomal dominant obesity caused by haploinsufficiency mutations in the melanocortin-4 receptor gene. Am J Hum Genet 1999;65:1501-1507.

- 35 Dempfle A, Hinney A, Heinzel-Gutenbrunner M, Raab M, Geller F, Gudermann T, Schafer H, Hebebrand J: Large quantitative effect of melanocortin-4 receptor gene mutations on body mass index. J Med Genet 2004; 41:795-800.

36 Biebermann $\mathrm{H}$, Krude H, Elsner A, Chubanov V, Gudermann T, Gruters A: Autosomal-dominant mode of inheritance of a melanocortin-4 receptor mutation in a patient with severe early-onset obesity is due to a dominant-negative effect caused by receptor dimerization. Diabetes 2003;52:2984-2988.

37 Tarnow P, Rediger A, Brumm H, Ambrugger $\mathrm{P}$, Rettenbacher E, Widhalm K, Hinney A, Kleinau G, Schaefer M, Hebebrand J, Krause G, Gruters A, Biebermann H: A heterozygous mutation in the third transmembrane domain causes a dominant-negative effect on signalling capability of the MC4R. Obes Facts 2008; 1:155-162.

38 Herold C, Becker T: Genetic association analysis with FAMHAP: a major program update. Bioinformatics 2009;25:134-136.
9 Becker T, Cichon S, Jonson E, Knapp M: Multiple testing in the context of haplotype analysis revisited: application to case-control data. Ann Hum Genet 2005;69:747-756.

-40 Stutzmann F, Vatin V, Cauchi S, Morandi A, Jouret B, Landt O, Tounian P, Levy-Marchal C, Buzzetti R, Pinelli L, Balkau B, Horber F, Bougneres P, Froguel P, Meyre D: Non-synonymous polymorphisms in melanocortin- 4 receptor protect against obesity: the two facets of a Janus obesity gene. Hum Mol Genet 2007;16:1837-1844.

41 Vaisse C, Clement K, Durand E, Hercberg S, Guy-Grand B, Froguel P: Melanocortin-4 receptor mutations are a frequent and heterogeneous cause of morbid obesity. J Clin Invest 2000;106:253-262.

42 Farooqi IS, Yeo GS, Keogh JM, Aminian S, Jebb SA, Butler G, Cheetham T, O’Rahilly S: Dominant and recessive inheritance of morbid obesity associated with melanocortin-4 receptor deficiency. J Clin Invest 2000;106: 271-279.

- 43 Xiang Z, Litherland SA, Sorensen NB, Proneth B, Wood MS, Shaw AM, Millard WJ, Haskell-Luevano C: Pharmacological characterization of 40 human melanocortin- 4 receptor polymorphisms with the endogenous proopiomelanocortin-derived agonists and the agouti-related protein (AGRP) antagonist. Biochemistry 2006;45:7277-7288.

-44 Yang J, Manolio TA, Pasquale LR, Boerwinkle E, Caporaso N, Cunningham JM, de Andrade M, Feenstra B, Feingold E, Hayes MG, Hill WG, Landi MT, Alonso A, Lettre G, Lin P, Ling H, Lowe W, Mathias RA, Melbye M, Pugh E, Cornelis MC, Weir BS, Goddard ME, Visscher PM: Genome partitioning of genetic variation for complex traits using common SNPs. Nat Genet 2011;43:519-525.

45 Tao YX: Molecular mechanisms of the neural melanocortin receptor dysfunction in severe early onset obesity. Mol Cell Endocrinol 2005;239:1-14.

46 Ho G, MacKenzie RG: Functional characterization of mutations in melanocortin-4 receptor associated with human obesity. J Biol Chem 1999;274:35816-35822.

47 Zhang F, Deng HW: Confounding from cryptic relatedness in haplotype-based association studies. Genetica 2010;138:945-950.

$\checkmark 48$ Tao YX, Segaloff DL: Functional analyses of melanocortin-4 receptor mutations identified from patients with binge eating disorder and non-obese or obese subjects. J Clin Endocrinol Metab 2005;90:5632-5638.

$49 \mathrm{Gu}$ W, Tu Z, Kleyn PW, Kissebah A, Duprat L, Lee J, Chin W, Maruti S, Deng N, Fisher SL, Franco LS, Burn P, Yagaloff KA, Nathan J, Heymsfield S, Albu J, Pi-Sunyer FX, Allison DB: Identification and functional analysis of novel human melanocortin-4 receptor variants. Diabetes 1999;48:635-639. 
50 Valli-Jaakola K, Lipsanen-Nyman M, Oksanen L, Hollenberg AN, Kontula K, Bjorbaek C, Schalin-Jantti C: Identification and characterization of melanocortin- 4 receptor gene mutations in morbidly obese Finnish children and adults. J Clin Endocrinol Metab 2004;89:940-945.

51 Nijenhuis WA, Garner KM, van Rozen RJ, Adan RA: Poor cell surface expression of human melanocortin-4 receptor mutations associated with obesity. J Biol Chem 2003;278: 22939-22945.

52 Calton MA, Ersoy BA, Zhang S, Kane JP, Malloy MJ, Pullinger CR, Bromberg Y, Pennacchio LA, Dent R, McPherson R, Ahituv $\mathrm{N}$, Vaisse C: Association of functionally significant melanocortin- 4 but not melanocortin-3 receptor mutations with severe adult obesity in a large North American case-control study. Hum Mol Genet 2009;18:11401147.

53 Kim DH, Shin SW, Baik JH: Role of third intracellular loop of the melanocortin-4 receptor in the regulation of constitutive activity. Biochem Biophys Res Commun 2008;365: 439-445.
54 Fan ZC, Tao YX: Functional characterization and pharmacological rescue of melanocortin-4 receptor mutations identified from obese patients. J Cell Mol Med 2009;13: 3268-3282.

55 Hughes DA, Hinney A, Brumm H, Wermter AK, Biebermann H, Hebebrand J, Stoneking $\mathrm{M}$ : Increased constraints on MC4R during primate and human evolution. Hum Genet 2009;124:633-647.

56 Tao YX, Segaloff DL: Functional characterization of melanocortin-4 receptor mutations associated with childhood obesity. Endocrinology 2003;144:4544-4551.

57 Lubrano-Berthelier C, Durand E, Dubern B, Shapiro A, Dazin P, Weill J, Ferron C, Froguel $P$, Vaisse C: Intracellular retention is a common characteristic of childhood obesity-associated MC4R mutations. Hum Mol Genet 2003;12:145-153.

58 Van Leeuwen D, Steffey ME, Donahue C, Ho G, MacKenzie RG: Cell surface expression of the melanocortin-4 receptor is dependent on a C-terminal di-isoleucine sequence at codons 316/317. J Biol Chem 2003;278:1593515940.
59 Xiang Z, Proneth B, Dirain ML, Litherland SA, Haskell-Luevano C: Pharmacological characterization of 30 human melanocortin-4 receptor polymorphisms with the endogenous proopiomelanocortin-derived agonists, synthetic agonists, and the endogenous agouti-related protein antagonist. Biochemistry 2010;49:4583-4600.

60 Santini F, Maffei M, Ceccarini G, Pelosini C, Scartabelli G, Rosellini V, Chiellini C, Marsili A, Lisi S, Tonacchera M, Agretti P, Chiovato $\mathrm{L}$, Mammoli $\mathrm{C}$, Vitti P, Pinchera A: Genetic screening for melanocortin-4 receptor mutations in a cohort of Italian obese patients: description and functional characterization of a novel mutation. J Clin Endocrinol Metab 2004;89:904-908.

61 Brumm H, Muhlhaus J, Bolze F, Scherag S, Hinney A, Hebebrand J, Wiegand S, Klingenspor M, Gruters A, Krude H, Biebermann H: Rescue of melanocortin-4 receptor $(M C 4 R)$ nonsense mutations by aminoglycoside-mediated read-through. Obesity (Silver Spring) 2012;20:1074-1081. 